\title{
SIR HARRY SMITH EN DIE GEESTELIKE SWAARD
}

Dit was met groot ingenomenheid waarmee die bevolking van die Kaap-kolonie die benoeming van sir Harry Smith as opvolger van sir Henry Pottinger tot Goewerneur verneem het. Hy was 'n soldaat, 'n krygsman met 'n roemvolle militêre loopbaan agter hom, nie alleen in Europa en in Indië nie, maar ook in Suid-Afrika. Deur sy optrede is die kaffer-oorlog van 1835 beëindig. Sy koms is met hoë verwagting tegemoet gesien, en toe hy op 1 Desember 1847 in die Kaap aangekom het, is hy met groot feestelikheid as 'n ou vriend begroet. Hy was dus nie 'n vreemdeling in Suid-Afrika nie, die bevolking het hy geken, al het hyself die Boere nie so goed begryp as wat hy gedink het nie. Sy optrede was die van 'n militêr, dapper ,electric in his every movement ... . very determined but very impulsive and theatrical"'. Hy het na SuidAfrika gekom, soos Theal dit uitgedruk het, „with a fully matured plan for the settlement of affairs North of the Orange." ${ }^{2}$ Die Boere wat buite die grense van die Kaap-kolonie gewoon het, wou hy onder die Britse soewereiniteit plaas, en hy wou dit bereik deur ook met vrome redenerings en met vroom woorde op hul gemoed te werk.

Reeds op 11 Desember 1847 het hy uit Kaapstad na die Oostelike grense vertrek om die sake te reël. In Port Elizabeth het hy die Kaffer kaptein Macomo ontmoet en nadat hy hom sy ontrou op berispende wyse verwyt het, het hy hom op die grond laat lê en sy voet op sy nek gesit en gesê: ,,This is to teach you that I am come hither to teach Kafirland that I am chief and master here, and this is the way I shall treat the enemies of the Queen of England." 3 'n Paar dae later het hy verskillende Kaffer-gebiede ten ooste van die Kaap-kolonie geannekseer en ingelyf, en in Kingwilliamstown het hy die Kaffer-opperhoofde sy voet laat soen as teken van hul onderwerping. ,The ceremony concluded by the High Commissioner shaking hands with all the chiefs, calling them his children, and presenting them with a herd of oxen to feast upon." 4 Op 7 Januarie 1848 het hy die opperhoofde 'n tweede keer saamgeroep, en nadat hy hul toegespreek het, moes hulle sweer om die Hoë Kommissaris as verteenwoordiger van die Koningin te gehoorsaam, en om toordery, geweldpleging aan vroue, moord, rowery en die koop van vroue te verwerp en om na die sendelinge te luister, en dan om elke jaar op daardie dag ieder ' $n$ vet os te bring as teken van erkenning dat hulle hul land van die Koningin gekry het. Daarop het hy na 'n wa gewys wat deur buskruit vir 'n ontploffing gereed gemaak was en gesê: "Look at that waggon and hear me give the word Fire!" Dit is aangesteek en die wa het in die lug gespring. "That is what I will do to you if you do not behave yourselves." Toe vat hy 'n stuk papier in sy hand en vra "Do you see this?" Hy skeur dit toe stukkies en strooi dit in die wind en roep:

'Eric Walker: A History of South Africa (1928) p. 237.

'Theal: History of South Africa Vol. III (1908) p. 261-262.

${ }^{3} \mathrm{G}$. C. Moore Smith: The Autobiography of Sir Harry Smith (1903) p. 586.

Autobiography p. 588-589. 
"There go the treaties! Do you hear? No more treaties". Hierop is hy noordwaarts en het 21 Januarie in Bloemfontein aangekom.

In die Vrystaat was daar verskillende politieke stromings vanaf die een uiterste van Engelse handelaars en grondspekulante en van die teenoor die Britsgesag lojaal gesinde Trekboere tot ander uiterste van die beslis Republikeinsgesinde Voortrekkers." 5 In Bloemfontein is aan sir Harry Smith twee adresse uit die lojaalgesinde kringe aangebied, een in die voormiddag en een in die namiddag. Toe hy op die adres van die voormiddag wou antwoord val sy oog op 'n ou grysaard van by die tagtig jaar wat onder die gehoor gestaan het, waarop hy hom spontaan roep om na vore te kom en hom toe sy eie stoel gee om op te sit en verskoning maak dat die ou man so lank moes staan. Met sulke dinge het sir Harry baie mense se harte gewen." ' In sy antwoord op die adres het hy onder andere gesê: "If all the Boers come and say that they wish to live under the British Government I will endeavour to aid them. I will have all or none... I will then cause churches to be built, schools established and roads made, traders to pay licences ... I mean to say that if the majority wish for the system I propose I will endeavour to carry it out and I shall feel thankful to God, if I am the means of bringing my friends from misery". Hy was van plan om in ooreenstemming met die Cape of Good Hope Punishment Act van 1836 die gesag tot aan die vyf-en-twintigste Suid-breedte graad uit te strek, want hy het ook aan die mense gesê: ,Now send an express at once to your friends at Mooi River for I am willing to forgive and forget the past and all will be settled, at least on this side of the Drakensberg."

In die namiddag het hy verder gesê: „As Colonel Smith I could do nothing, but as Governor I can do everything . . . you shall possess all the rights and privileges of citizens of the Colony and as soon as you have towns you shall be granted municipalities ... but you must clearly understand that the whole body of Emigrants must come into your way of thinking. I do not mean every individual because I know in every Society there are fools, but a majority of four in five, because I know the four can keep the fifth in the right way. I shall call upon you to bear arms to aid me in keeping the peace both among Whites and Blacks. When I have heard from all the Boers on this side of the Drakensberg I shall know what to do".

Verder het hy 'n samespreking gehad met Adam Kok die opperhoof van die Griekwas en sy Raad. Toe Adam Kok nie inskiklik was nie en besware teen die voorgestelde verdrag gemaak het, het sir Harry Smith woedend geword en gesê: „What, am I the conqueror of all Kaffirland to be thwarted by a black fellow like you? There's your treaty and there's the door." Adam Kok en sy Raad het hul lam geskrik veral toe na die balk van die kamer gewys is. 'n Balk was 'n bedreiging om aan opgehang

${ }^{5}$ Vgl. M. C. E. van Schoor: Politieke Groeperinge in Transgariep, in Argief-Jaarboek vir S.A. Geskiedenis 1950 Deel II bls. 1-186.

'T. F. Midgley: The Orange River Sovereingty in Araief-Jaarboek 1949 Deel II p. 55. 
te word. Hulle het dan ook sommer met die voorgestelde reëlings ingestem. Met sy vertrek uit Bloemfontein het sir Harry Smith aan Moroko gesê: ,You and Moshesh are two of the greatest chiefs under Her Majesty. Keep peace, attend to your Missionaries and then your cattle will get fat and you will go to Heaven."

Op 27 Januarie het hy op Winburg 'n ontmoeting met Mosjesj gehad, 'n ontmoeting wat weer ewe teatraal en eksentriek was. So het hy onder andere hierdie Kafferopperhoof en geslepe diplomaat by die hand gevat en aan die Boere wat daar was, voorgestel as die man aan wie hulle die vrede wat hul tot dusver geniet het, te danke had. Van die lojaalgesinde Trekboere het hy weer 'n adres ontrang met die versoek om die Britse gesag oor die gebied te vestig. Hy het toe verklaar dat dit sy plan was om die Koningin se soewereiniteit oor al die gebiede waar Emigrante woon, te vestig. Op versoek van die lojaalgesinde Kerkraad het hy die hoeksteen van die kerkgeboutjie gelê, en hy het dit gedoen terwyl ,he was bathed in tears and speechless with emotion." " Hy het $£ 20$ vir die bou van die kerkie geskenk en 'n lening uit die koloniale fondse op die pond vir pond basis beloof.

Van Winburg is sir Harry Smith na Natal om dinge te probeer regmaak, want die Boere was daar baie geskok deur die beledigende optrede van die Kaapse Goewerneur, sir Henry Pottinger. Op 20 Julie 1847, het die Natalse Voortrekkers 'n groot byeenkoms aan die Tugelarivier gehou en Andries Pretorius gekies om na Grahamstad waar die Goewerneur op daardie tydstip vertoef het, en die toestand en verwarring wat daar geheers het, aan hom voor te lê en persoonlik met hom te bespreek. Maar toe Pretorius na 'n moeitevolle reis in Grahamstad aankom, het sir Henry Pottinger op hooghartige wyse geweier om hom te ontvang en te woord te staan.

Sir Harry Smith het besef watter onvergeeflike flater met hierdie optrede begaan is en dit was een van die redes waaron hy so 'n haas had om na Natal te gaan. Hyself het die volgende beskrywing gegee van die situasie wat hy daar aangetref het: „On my arrival at the foot of the Drakensberg Mountains, I was almost paralyzed to witness the whole of the population, with few exceptions ,trekking'! Rains on this side of the mountains are tropical, and now prevail-the country is intersected by considerable streams, frequently impassable-and these families were exposed to a state of misery which I never before saw equalled, except in Massena's invasion of Portugal, when the whole of the population of that part of the seat of war abandoned their homes and fled. The scene here was truly heart-rending. I assembled all the men near me through the means of a Mr. Pretorius, a shrewd, sensible man, who had recently been into the Colony to lay the subject of dissatisfaction of his countrymen before the Governor, where he was unfortunately refused an audience, and returned after so long a journey expressing

'Theal Vol. III p. 265. 
himself as the feelings of a proud and injured man would naturally prompt." 8

Dit was in die begin van Februarie 1848 dat sir Harry Smith in Natal aan die Tugelarivier onder die Voortrekkers vertoef het wat besig was om daar weg te trek. Hulle het Andries Pretorius as hul woordvoerder benoem om hul griewe aan die Goewerneur voor te lê. Hy het dit op duidelike wyse gedoen en daarop gewys hoe hul genoodsaak was om hul plase en besittings te verlaat en weer die wildernisse moes intrek. Hy was in sy toespraak baie bewoë en daar was onder die anwesige Voortrekkers byna geen oog wat droog was nie. Sir Harry Smith het sy bes gedoen om hulle te beweeg om na hul plase terug te gaan, maar hoe begerig hul ook al was om dit te doen, het hul tog met nadruk verklaar dat hul die gevare van die binnelande waar hulle hulself kon verdedig, verkies het bo die verdere lewe onder die Britse bewind in Natal.

Die Tugela was baie vol en sir Harry Smith was daardeur gedwonge om 'n paar dae oor te bly voordat hy sy reis verder kon hervat, en Pretorius het hom toe na sy kampeerplek saamgeneem. Maar hul moes eers nog ' $n$ ander spruit deurgaan wat net so vol was, en Pretorius het aan sir Harry 'n perd gegee wat aan diep waters gewoond was, en ook twee spanne osse om sy wa met sy bagasie oor te bring. Toe hulle rustig in die tent van Pretorius kon praat het sir Harry baie sterk daarop aangedring dat die Trekkers moes teruggaan en het hulle ,gouden bergen" beloof, en nadat hy aan Pretorius , veel geld heef gepresenteer", ${ }^{9}$ en dit nie gehelp het nie, het sir Harry 'n proklamasie uit sy sak gehaal waarmee hy die hele gebied ten ooste van die Drakensberg tussen die Oranje en die Vaalrivier as Britse gebied geannekseer het, en tewens het hy aan Pretorius gesê dat as hy hom met dieWêreldlike Swaard nie onder kon kry nie, hy dit met die Geestelike Swaard sou doen. Hierdie dreigement het 'n groot indruk op die ou Transvalers gemaak. Dit het meer as iets anders bygedra om te laat besef watter groot gevaar 'n inskakeling met die Kaapse Kerklike Organisasies vir die nasionale strewe van die our Transvalers was. Dit was een van die redes waarom die Eerste Algemene Kerkvergadering op 8 Augustus 1853 met nadruk en beslistheid 'n inlywing onder die Kaapse Sinode verwerp het. Ds. N. J. van Warmelo wat in 1863 in Transvaal gekom het en daardie ou mense goed geken het en hul oor die Kerklike verlede uitgevra het, en materiaal versamel het vir 'n Kerkgeskiedenis van ou-Transvaal, verhaal hoe een van die ,,velerlei redenen" wat ten gunste van die verwerping van 'n inlywing aangevoer is, was „omdat man zich de bedreiging herinnerde van ,het geestelyke Zwaard' waarvan sir Harry Smith had gesproken". ${ }^{10}$ En toe daar in 1855 in die nuwe nedersetting Utrecht 'n groep mense was wat kerklik wel onder die Kaapse Sinode wou ressorteer, het Kommandant-Generaal M. W. Pretorius hulle as volg gewaarsku: ,Was het oot den Gouverneurs

${ }^{8}$ Blouboek No. 9801848 p. 211-212.

'Staatsargief Pretoria, R 164/49.

${ }^{10}$ Ds. N. J. van Warmelo: Een Herinnering aan Ds. Dirk van der Hoff (1881) bls. 10. 
van die Kaapstad geluk met Maneveste of met Bommen en Canonnen ons te verschrikten of in te neemen; en als dan de Wêreldlijke Zwaard zoo manmoedig afgeweerd geworde zijn, zoude wij zelf vrage ons door de Geestelijke Zwaard te onderwerpen?" 11

Hier verwys Pretorius op die mees ondubbelsinnige wyse na die bedreiging van die Geestelike Swaard. Met die "maniveste” waarvan Pretorius praat, sinspeel hy op die „Manifest of Openbare Verklaring” wat sir Harry Smith op 29 Mart 1848 op die proklamasie waarmee hy die Vrystaat as Britse gebied geannekseer het, laat volg het, en waarin hy op teatrale wyse op die godsdienstige gevoel van die Voortrekkers probeer werk het om hul met die anneksasie tevrede te stel. ${ }^{12}$

Daar is in later jare meermale sonder die minste bewysgronde deur persone wat nie Voortrekkers of Voortrekker-afstammelinge is nie ontken dat sir Harry Smith ooit met die Geestelike Swaard sou gedreig het, en die argument wat dan hierdie ontkenning moet staaf, is die feit dat daar nie 'n proklamasie van sir Henry Smith bestaan nie waarin hierdie dreigement in voorkom. Maar nooit is van gesaghebbende kant beweer dat sir Harry Smith dit in 'n proklamasie gedoen het nie, maar dat hy dit in 'n persoonlike gesprek met Andries Pretorius gedoen het. en wel toe hy aan die Tugela in sy laer was.

Die noodwendige gevolgtrekking van hierdie ontkenning kan dan ook nie anders wees nie as dat die ou Voortrekkers wat van hierdie bedreiging met die Geestelike Swaard gepraat het, die hele verhaal uit hul duim sou gesuig het. Dit is tog eienaardig om aan die eenkant vir die Voortrekkers monumente op te rig, en vir Andries Pretorius selfs 'n standbeeld, en dan tegelykertyd aan die anderkant 'n bewering te wil maak waarvan die logiese gevolgtrekking alleen kan wees dat hierdie persone baie leuenagtige mense moes gewees het. Selfs hul mees felle bestryders van Engelse kant het nooit hul waarheidsin op so 'n growwe wyse in twyfel getrek nie. Maar waarom word hierdie dreigement van sir Harry Smith dan so skaamteloos ontken? Die Kaapse Kerk kan tog seer seker nie verantwoordelik gehou word vir wat sir Harry Smith gesê het nie, of is die rede van die ontkenning miskien omdat sommige mense hul vandag skaam oor die anti-nasionale houding van baie Kaapse Kerklike leiers wat in daardie dae so 'n afwysende houding teenoor die nasionale strewe van die Voortrekkers aangeneem het? Maar 'n ontkenning is nodeloos. Cok daardie ou Kaapse Kerkleiers was kinders van hul tyd. Bowendien bewys die feite uit die Geskiedenis ten oorvloede dat die Kaapse Kerk inderdaad as 'n Geestelike Swaard teen die nasionale strewe van die Voortrekkers gebruik is. Die betoogtrant van die mense wat hierdie dreigement van sir Harry Smith wil ontken, is soms eienaardig. So is byvoorbeeld beweer dat dit ,ondoenlik" is om ds. Andrew Murray se „vereenselwiging met 'n anti-republikeinse seksie in 1854 wat die ontruiming van

IIStaatsargief Pretoria R897/55.

12J. H. Malan: Die Opkoms van 'n Republiek (1929) bls. 213. 
die Soewereiniteit beveg het, as onvaderlandsliewend en onoordeelkundig te veroordeel".

Toe dit in 1893 weer op apodiktiese wyse sonder enige grond ontken is dat sir Harry Smith ooit met die Geestelike Swaard gedreig het, het drie persone, nafamilielede van generaal Andries Pretorius, wat aldrie saam met hom uit Natal weggetrek het, en wat by die dreigement aanwesig was en dit aangehoor het, 'n verklaring in De Volksstem van 19 Mei 1893 gemaak, 'n verklaring wat dan ook nooit weerspreek is nie. Dit het as volg gelui:

„,aan den Editeur van De Volkstem,

Knoppieslaagte, 19 Mei 1893.

„,Mijnheer,- -vergun ons eene plaats in uw geëerd blad. Wij hebben onlangs gehoord, dat daat personen zijn wat ontken, dat die Gouverneur Harrie Smith gezegd heeft aan Commandant A. W. J. Pretorius, dat als hij de burgers niet kan onder hare Majesteit inschiet met bommen en kannonnen, maar ik zal de Geestelijke Zwaard stuur. Harrie Smith heeft dat gezegd bij Dongela met onze uittrek uit Natal naar Transvaal in het jaar 1848."

Nou wil ons die personen, wat dat ontken, vier vragen doen, ons als Voortrekkers.

„Ten eerste: Het julle, zooals Commandant Generaal A. W. J. Pretorius gesproken met die Gouverneur?

Ten tweede: Het julle, zooals Gideon S. Pretorius, zijn wagendrijver geweest of hem door de rivier Dongela geholpen, toen er geen brug was?

Ten derde: Was julle, zooals Gideon S. Pretorius zijn tolk met de Zoelahs op de reis en Meneer Soude de tolk in Hollandsch en Engelsch?

Ten vierde: Het julle, zooals Gideon S. Pretorius, een pak kleeren present gekrijg voor die trouwe dienst gedaan aan die Gouverneur?

Vrienden, wilt gij nog twijfelen? Wij zullen alles bewijs met getuigen wat hier geschreven staat! De oude heer Joggom Prinsloo, die reeds overleden is, heeft voor zijn dood eene schriftelijke verklaring afgeleg.

Toen die Gouverneur met Commandant Generaal A. W. J. Pretorius gesproken heeft, zat Prinsloo voor de tent met G. S. Pretorius, H. A. Pretorius, H. P. A. Pretorius, M. P. W. Pretorius en vijftig andere personen.

Wij verlangen niet die honderd pond, wat ons verteld is, dat Meneer Akkerman voor bewijs van die woorden van Harrie Smith uitgeloof het. Wij willen dat niet voor geld bewijs, maar wel uit liefde voor onze natie.

Ook Andrew Murray het omstreeks 1850 diezelfde woorden gebruikt op de plaats van Kasper Kruger achter Magaliesberg.

Wilt gij het nog betwisten dat het niet gebeurd is? Dan willen wij u alleen een vraag doen: Is die geestelijke Swaard niet in ons Kerk gekomen en alles in tweedracht gemaaid? 
Als $u$ verder die zaak wil hoor, wees dan zoo goed en kom bij ons; wij zullen u verder inlichting geven. Het is nog alles in ons geheugen.

G. S. PRETORIUS.

M. P. W. PRETORIUS.

H. P. PRETORIUS.

Hierdie dreigement met die Geestelike Swaard het heeltemal by die aard en die hele handelwyse van sir Harry Smith gepas, soos dit weerspieël word in sy wyse van optrede teenoor die naturelle kapteins. Eers is hy godsdienstig en salwend, en as dit nie help nie is hy weer vol dreigemente en grootpraat en blut. So was hy ook nadat hy tevergeefs met mooi woorde en fraaie beloftes probeer het om Andries Pretorius oor te haal om nie uit Natal weg te trek nie. In sy proklamasie waarmee hy op 3 Februarie 1848 die Vrystaat ${ }^{13}$ geannekseer het, het hy al met die uitvoering van sy dreigement begin toe hy gedekreteer het: ,The expense of the Government aforesaid, shall be vested in a fund, under the control of a Comnission, composed of members of the Dutch Reformed Church, appointed by Her Majesty's High Commissioner, for the erection of churches on such spots as may be selected and sanctioned, and for the provision of ministers...". Op 29 Maart 1948 het hy in Kaapstad 'n "Manifest of Openbare Verklaring"' gepubliseer ${ }^{14}$ wat veral teen Andries Pretorius gemik was en wat moes dien as "uitleg" van sy proklamasie van 4 Februarie ,, van de beweegredenen welke mij noopten om een Gouvernement daar te stellen over misleide, teleurgestelde misnoegde menschen, die uit het Land hunner Vaderen zijn uitgeweken, de woningen daar zij in groot geworden zijn hebben verlaten, afgescheiden van bloedverwanten en vrienden, de gezellige omgang met wien strekte tot hun geluk,-van hunne leeraren, hunne kerken en gevolglijk ook hun God". Koddiger staatstuk is nooit deur 'n Goewerneur in Suid-Afrika uitgestuur nie as hierdie „Manifest of Openbare Verklaring” wat as „uitleg” van sy inlywingsproklamasie van 3 Februarie moes dien. Hy vertel daarin hoe 'n klompie Voortrekkers by hom kom kla het: ,Zij schilderden den staat van ellende in welken zij verkeerden uit gebrek aan Kerken en Wetten; verklaarden dat zij in geen tien jaren eene Kerk hadden gezien; zij konden hunne dochters niet getrouwd krijgen, noch hunne dooden begraven., ${ }^{115}$ En dan rig hy verder die woord persoonlik tot hierdie mense wie se gebied deur hom vir die Britse kroon geannekseer is: „,Gij hebt inderdaad sedert eenige jaren geen Gouvernement gehad. Zijt gij gelukkiger? Zijt gij rijker? Zijt gij betere Christenen? Gij zijt ellendig, gij zijt armen, de

\footnotetext{
${ }^{13}$ Die benaming „Vrystaat" is vanselfsprekend van later datum, maar word gemakshalwe hier al gebruik.

1"In Dr. H. P. N. Muller: Oude Tijden in den Oranje Vrystaat (1907) bls. 18-25.

${ }^{15}$ Eienaardig! Dit was juis Sir Harry Smith wat die huwelike van die republikeinsgesinde Voortrekkers wat deur hul landdroste gesluit is nie wou erken nie en twee predikante Ds. William Robertson en Ds. P. E. Faure opgedra het om hulle te gaan oortrou waarby die komiese hom voorgedoen het dat hulle 'n paar oorgetrou het waarvan die vrou reeds 'n tyd van te vore oorlede was. En dan sy hewering dat die mense by hom sou gekla het dat hulle hul dooies nie kon begrawe nie sy hulp was daarvoor tog nie nodig nie.
} 
helft uwer zijn geruineerd. Gij wijkt af van uw geloof, zonder leeraars om mede te raadplegen of in te vertrouwen, terwijl uwe broeders uwe neven, uwe vrienden onder een regtvaardig en vrij Gouvernement gelukkig en tevreden zijn, wol en koorn afschepen, kostbare paarden, schapen en vee verkoopen en alle zegeningen genieten welke een goed geweten opleveren en beschaving en godsdienst daarstellen, Zondags naar de Kerk gaan met hun fraaije spannen paarden en wagens met hunne vergenoegde vrouwen en kinderen, terwijl uwe Zondagen doorgebracht worden in uwe ellendige hutten, niet in de goede huizen waarin gij opgevoed zijt, maar woest en onvergenoegd.

„Laat ons dan ten eerste de werkdadige uitkomst overwegen van mijn vaderlijke gevoelens tot uwe welvaart, ter voldoening van uwe vrienden en betrekingen binnen de Kolonie, die zoo zeer begeeren $u$ bevestigd te zien in de beschaving met een huis om in te wonen, een school voor uwe kinderen en eene Kerk om in te bidden."

En nadat hy al die goeie dinge opgenoem het wat hy in 'n paar weke tyds as met 'n towerslag in die Vrystaat tot stand gebring het waar daar eers twyfel en onsekerheid was, sê hy: „Deze staat van twijfel en onzekerheid is dadelijk veranderd door mijn bezoek." En nadat hy nog verder op die seëninge van sy besoek gewys het, vervolg hy: „Iedere penning van de inkomsten, voorspruitende uit de erfpacht van u geeischt, is tot uw voordeel, tot uwe regeering, tot uwe scholen, tot uwe Kerken, tot uwen God. Gij gaat's avonds naar bed, den Almachtigen beschermer der wêreld dankende: ,Dit is mijn huis, mijne eigene onbetwiste woning, hier ben ik te huis, hoe aangenaam! Mijne vrouw zal worden beschermd, mijne kinderen opgevoed, mijne Godsdienst gevestigd, markten zullen worden opgerigt, tot mijn tijdelijke voordeel". Gij slaapt den slaap des geluks, want God is met u. Gij staat op in den morgen, en met Gode verheerlijkende uitstorting van dankbaarheid ziet gij, voordat gij u naar uwen dagelijkschen arbeid begeeft, uwe vrouw en uwe kinderen om $u$ heen zonder vrees of beving, zonder twijfel of onzekerheid. Opgewondenheid wordt door tevredenheid opgevolgd en ten eerste fluistert de stem: "Wij zeggen onze oude vriend Kolonel Smith dank voor het geen hij gedaan heeft." Niet lange duurt het of de stem roept luidkeels uit: ,,Smith is onze Gouverneur, hij is het die ons aangespoord heeft ons zelven te regeren, onder zijne minzame zorg, wij danken hem als onze Gouverneur."

En dan waarsku hy hulle om hul nie deur ,,aanhitzers" te laat opwin om ,,toe te laten, vrede, geluk en genoegelijkheden, na in uw bereik, van uw deuren te dryven." Sy enigste oogmerk toe hy as 'n ,,balling" en "wonende in een wagen" onder hulle moes ",ondzwerven", was ,,om aan oude vrienden goed te doen". Hy het baie soldate, maar hy haat die oorlog en het die vrede lief. „Maar", vervolg hy, ,er sijn oorzaken, zoo heilig aan den Heer en in het oogmerk den wêreld, dat zij de tusschenkomst van een legermagt noodzakelijk maken".

Die laaste deel van hierdie manifes word hier verder in sy geheel aangehaal: 
$\mathrm{Nu}$ mijne vrienden! Mijne halfverloren vrienden, en aarzelende Christenen! Ik heb u aangesproken als Kolonel Smith, ik heb mij beroepen op uwe gevoelens als menschen, als vaders van huisgezinnen, als redelijke menschelijke wezens, onsterfelijke zielen bezittende. Ik heb gedaan wat ik kon zoo ver mijn vermogens en krachten mij toelieten. $\mathrm{Nu}$ spreek ik tot $\mathrm{u}$, niet meer als Kolonel Smith, maar als de Gouverneur dezer volksplanting, en ik Proclameer aan $\mathrm{U}$, dat ik de voorzieningen van de Proclamatie, die ik tot uw uitsluitelijk voordeel en op uwe eigene begeerte heb vervaardigd, ten uitvoer zal brengen of in de poging sneven zal. De twistzieke volksschreeuwer ${ }^{16}$ zal sidderen bij den naam, die hij nu zelfs eerbiedigt en voor welken gij allen wijd en zijd en luidkeels uwe gehechtheid hebt verklaart. Gij weet wel, dat ik nooit mijn woord heb verzaakt. Gij weet wel, want velen van $U$ hebben met mij in de oorlog gediend, de snelheid waarmede ik het zwaard hanteer. Denk niet, dat ik mij van de middelen beroofd heb door het naar huis zenden der troepen. Ik zeg $u$, en ik zeg $u$ als een opregt en eerlijk man, ik houd een magt in gereedheid van kanonnen, ruiterij en beproefde Britsche soldaten, die binnen vijftien dagen onder $\mathrm{u}$ zullen zijn, mannen geschikt om stoutere harten dan de uwe te doen beven. Toen ik het bevel over $\mathrm{u}$ had waart gij dapper; nu hebt gij geen opperhoofd waarin gij vertrouwen stellen kunt; uwe harten zijn in de verkeerde plaats, omdat uwe zaak onregtvaardig is; eenige weinige domme misnoegde menschen trachtende de menigte aan te hitsen, spreekt gij van wederstand en bijeenkomsten, gij, die twee jaren geleden door een klein getal dragonders als schapen omver gereden werdt! Durft gij u verbeelden, dat gij in staat zijt te doen, het geen eene menigte van oproermakende windzakken nimmer hebben kunnen doen, de ongeoefenden, de geoefende legermagt van een geregeld Gouvernement te wederstaan en een langdurige wederstand vol te houden? Dan-ach, welk een afschuw heb ik zelfs voor den naam van oorlog en beroering. De vele veldslagen, welke ik bijgewoond heb, komen als schimmen voor mijnen geest. Doch even als ik den oorlog haat, zal ik deszelfs verschrikkelijke kracht handhaven, wanneer gij mij van uwe toegenegenheid afscheidt. Indien gij mij noopt het noodlottig zwaard te zwaaijen, na al het geen ik voor $U$ beproefd heb, zoo blijve de misdaad op uw eigen hoofd, en hoewel mijne troepen in triomf zullen juichen, zal ik weenen, gelijk gij mij hebt zien doen, over de gevallenen, de verslagenen, de misleiden; uwe landen zullen $u$ ontnomen worden, uwe huizen vernield, uwe kudden weggevaagd, uwe eigene harten zwartgeverwd door goddelooze ondankbaarheid; en uwe getrouwe, uwe edelmoedige vriend, die zich ten uwen behoeve heeft afgesloofd, veranderd in een wreker van het kwaad. Gij zult worden gelijk de Ismaelieten van ouds, "uwe hand zal tegen elk man zijn en elk mans hand zal tegen u zijn". "Wraak is de mijne," zegt de Heere: en in zijnen naam en tot nut van zijn schepselen zou ik hen tuchtigen, die ik zoo bemin en wien ik getracht heb te bewijzen dat ik zulks doe.

${ }^{18}$ Hiermee word generaal A. W. J. Pretorius bedoel. 
Fr bestaan grenspalen voor die deugdzaamste gevoelens in deze wereldsche en onzekere beproeving des levens. Komt mij te hulp, gelijk ik $\mathrm{u}$ verzoek om dezelfde te bewaren: en zooals in weldadige en onbedorvene harten de verhevenheid van Godsdienst ons door moeijelijkheden van dit voorbijgaand leven voortvoert, laten wij te zamen bidden:

Heer van alle kracht en Magt, Beschikker van alle dingen, goed en kwaad, verwaardig $U$ neder te zien op ons zwakke en zondige schepselen; leer ons wie onze ware vrienden zijn; bewaar en versterk ons in alle beproevingen en verzoekingen; behoed ons tegen de slechte daden van goddelooze menschen; leer ons $U$ te aanbidden met onze harten, onze zinnen, onze zielen, $\mathrm{U}$ toegedaan door Jezuz Christus; rigt onze harten en onze daden jegens onze naasten; leer ons alzoo te leven dat onze loop in dit leven ons brengen mag tot het eeuwige leven; leer ons na een vreedzaam leven uit te zien na de vereeniging in den hemel de bron van onze hoop op aarde, de gelukkige plaats der rust voor onze onsterfelijke zielen. Wanneer wij het sterfelijke kleed moeten afleggen en op het doodsbed nederliggen, laten wij Vrede hebben met $U$, o Heer! Vrede met de wereld en Vrede met onze eigene harten!! Schenk ons dit, o Heer, onze Almachtige God, door Jezus Christus.--Amen.

\section{H. G. SMITH.}

Gouvernementshuis, 29 Maart 1848.

Sir Harry Smith het nou probeer om Hendrik Potgieter teen Andries Pretorius op te maak. Op 28 Mei skryf hy uit Kaapstad aan Potgieter ${ }^{17}$ en vermeld sy manifes van 29 Maart en begin dan met sy vroom doenery: „Mijne enigste begeerte is om zoo veele van mijne waardige oude vrienden te behouden in die vreeze en liefde van God, door Zijnen Zoon Onzen Heer Jezus Christus, om een liberaal Gouvernement opgerigt te zien over allen en in eene groote mate door ulieden zelven". Potgieter moet hom maar laat weet wat hy nodig het want hy, hulle "ouden vriend" wil hul so graag gelukkig sien. En dan waarsku hy om hom nie deur Pretorius te laat mislei nie. „De Almagtige God zal over de daden en handelingen van woedende en eerzuchtige menschen oordeelen, en hun loon zal zijn naar hunne verdiensten".

Reeds op 15 Mei het Potgieter aan sir Harry Smith geskryf ${ }^{18}$ en sy teleurstelling laat blyk met laasgenoemde se proklamasie, en sy aanspraak op die gronde tussen Vals- en Vetriviere wat hy in 1836 van die naturelleopperhoof Makwana geruil het beklemtoon en besware gemaak teen die anneksasie daatvan. Sir Harry Smith het hom op 22 Junie hierop geantwoord ${ }^{19}$ en onomwonde gesê: „Gij zijt allen, en moet voor altoos blyven Britsche onderdanen", dat hulle 'n geringe erfpag moet betaal vir die betaling ,van uwe Magistraten, Landmeters, Veld Commandanten en Veldkornets, Predikanten, Schoolmeesters, Kerken en Schoolen." Hulle sal beskerm word, ,,en gij zult spoedig Kerken en Scholen hebben."

${ }^{17} \mathrm{R} .142 / 48$. Voortrekker-Argiefstukke, bls. 318-319.

${ }^{19}$ R.141/48. Voortrekker-Argiefstukke, bls. 316-318.

${ }^{1}$ R.143/48. Voortrekker-Argiefstukke, bls. 330-331. 
Die republikeingesindes wou hul nie aan die aaneksasie van sir Harry Smith onderwerp nie, en het 'n paar man na Transvaal gestuur om Pretorius te vra om te kom help, waarop hy hom na die Vrystaat gehaas het. Sir Harry Smith het hom hierop voëlvry verklaar en 'n prys van $£ 1,000$, later verdubbel tot $£ 2,000$, op sy hoof geplaas, en het Kaapstad verlaat om na die Soewereiniteit te jaag. Op 10 Augustus het hy vanaf Colesberg laat weet dat hy ,gewapende rebellen" nie kan sien en ook nie kan onderhandel nie. ${ }^{20}$ Voordat hierdie brief nog ontvang was het Pretorius aan sir Harry geskryf en gevra om hom aan die noordelike oewer van die Oranjerivier te ontmoet, laasgenoemde wou egter nie met wat hy genoem het die ,damned rebels" onderhandel nie. Hy het op 14 Augustus nog weer ' $n$ brief geskryf as antwoord op 'n brief uit die ,,rebel Camp" waarin hy begin het om hom te verontskuldig dat hy dit nie die vorige dag geskryf het nie, maar dit kon nie, want toe was dit ,Zondag, een dag van Rust"!!!

Op 17 Augustus rig sir Harry Smith 'n ,,waarschuwing aan de Rebel Boeren". ${ }^{21}$ Ook hierin is vroom praatjies en dreigemente met groot woorde deurmekaar vermeng. Na sy eerste dreigement gee hy 'n opsomming van al die goeie dinge wat hy vir die Voortrekkers gedoen het, waaronder die volgende: ,Ik heb alle huwelijken gewettigd. ${ }^{22}$ Ik heb twee Godsdienst Leeraren aan het komen uit Holland." ${ }^{23}$ En dan gaan hy ook flink te keer teen die ,zichzelve noemende Commandant-Generaal" Pretorius wat deur ",bangmaking" die mense gedwing het om hom te volg, maar , ik zeg hem, dat ik er van bewust ben dat vier-vyfde deelen der menschen van bezittingen ten gunste zijn van de mildadige regering die ik bepaald heb tot voordeel van allen, tot de Kerk van Christus-en tot vrede.” En iets verder: „Bloed zal niet ophouden om te vloeijen tot tijd en wijl dat vrede en rustigheid hersteld zullen zijn, en Rebellen uit het land verdreven; en wanneer vrouwen weenen, zullen zij, Rebellen, de moordenaars zijn van hunne mannen, zoons en broeders."

„Kiest dus oorlog of vrede,—de een zal ik met wakkerheid opvolgen, de andere verzekeren tot voordeel van goede mannen en Gods Kerk-

${ }^{20}$ R.148/48. Voortrekker-Argiefstukke, bls. 334.

${ }^{21}$ Cape of Good Hope Govt. Gazette, July 27, 1848.

${ }^{22}$ En tog het hy 'n paar maande later aan twee predikante ds. William Robertson en ds. P. E. Faure opgedra om die mense wat deur Voortrekker-landdroste getroud was, weer oor te trou. Daar was as vanselfsprekend geen tyd of geleentheid om die huweliks-afkondigings op drie agtereenvolgende Sondae af te lees nie en daarom het sir Harry Smith, soos ds. Faure dit op die Sinode te Kaapstad verhaal het, hulle toegestaan om al die drie aflesings somaar op een en dieselfde Sondag te doen, sien Het Volksblad 13 November 1862. Met hier oortrouery is daat selfs 'n paar oorgetrou waarvan die vrou alreeds oorlede was.

${ }^{23}$ Dit was Andrew Murray, seun ds. Andrew Murray van Graaff-Reinet en Dirk van Velden wat predikant in Belgie was en in 1849 op aandrang van sir Harry Smith na SuidAfrika gekom het. Van Velden het in Nederland nie die status van predikant gehad nie en was nie beroepbaar nie omdat hy nie die vereiste opleiding vir predikant gehad het nie. Hy is op 24 Januarie deur sir Harry Smith as predikant vir Winburg aangestel. Van Velden was 'n hoogs onsimpatieke persoon dikwels ru en onhebbelik in sy optrede in alle opsigte ' $n$ teenstelling met Andrew Murray wat fyn beskaafd was, simpatiek in sy optrede en van 'n vrome lewenswandel, 
en ik zal zoodanige militaire posten oprigten als wat in den tor komenden tyd aan beleediging zullen bloodgesteld wezen."

„Pretorius is een banneling, een man die vogelvrij verklaard is,-en $\mathrm{ik}$ zal nooit met hem eenige communicatie houden."

„De Proclamatie, twee duizend Ponden sterling presenteerende voor hem in hechtenis te nemen, blijft in zijne volle kracht."

„Het is mij bekend dat sommige van u Rebellen groote sommen gelds in de Kolonie hebben. Wees voorzichtig, indien gij een schoot vuurt, dat ik zulks niet in beslag neme om te assisteren in het afdoen van die kosten dezer inbreuk die gijlieden zoo verraderlijk en op zoo een verraderlijke wijze aangevoerd hebben, en tot het terugbetalen, waar zulks mogelijk is, aan de goede mannen, voor de schulden die zij geleden hebben, door uwen inval, uwe dreigementen en uwe roverijen."

Op 29 Augustus het dit te Boomplaas op 'n botsing uitgeloop. Die Boere moes die onderspit delf. Sir Harry Smith wat in 1810-1812 die oorlog in Spanje en Portugal meegemaak het en aan verskillende gevegte daar deelgeneem het, asook aan die veldslag van Waterloo in 1815 , het tog, gewend as hy was aan grootspraak en groot woorde, aan die regering in Engeland van hierdie botsing te Boomplaas durf skryf as „one of the most severe skirmishes ever, I believe, witnessed," en daaraan toegevoeg „No prisoners were taken, for none of the rebels would yield".

Sir Harry Smith het nou probeer om deur middel van allerhande vleiery Hendrik Potgieter aan sy kant te kry. Al die gronde wat Potgieter tussen Vals- en Vetrivier van Makwana geruil het, kon hy behou, maar onder Britse gesag. Potgieter het geweier, waarop Southey namens sir Harry Smith verklaar het dat die Voortrekkers ten noorde van die Vaalrivier Britse onderdane was en sou bly, onderworpe aan die koloniale howe. Hulle landdroste en veldkornette en ander amptenare kon hul wel self kies, maar die name moes vir die finale aanstelling eers aan die Goewerneur voorgelê word! Die Transvalers kon soiets egter nie aanvaar nie.

In Oktober 1848 het die lojaliste uit die streek van die Modder- en Rietriviere die Sinodale Kommissie aan die Kaap gevra om tog weer 'n paar besoekende predikante na hulle te stuur. Die Moderator, ds. P. E. Faure, en die Aktuarius, ds. A. Faure, het hulle met sir Harry Smith in verbinding gestel en hy was so oortuig van die invloed wat 'n soortgelyke deputasie die vorige jaar in die Vrystaat gehad het „op de bevordering van de rust des lands", dat hy nie alleen sy verlange te kenne gegee het dat daar weer 'n soortgelyke deputasie deur die Sinodale Kommissie gestuur moes word nie, maar ook dat hy bereid was dat die onkoste deur die Britse Goewerment van die Kaap-kolonie gedra sou word. Dr. William Robertson en ds. P. E. Faure wat ,in accordance with the wishes" van sir Harry Smith ${ }^{24}$ as deputasie benoem is, het egter gevra dat hierdie onkoste eers na hul terugkoms aan hulle uitbetaal sou word ,,apprehending it might injure the cause if the expenses were advanced by the Gov${ }^{24}$ A. Dreyer: Die Kaapse Kerk en die Groot Trek (1929) bls. 133, 
ernment." ${ }^{25}$ Die bedoeling is duidelik: dit moes vir die republikeinsgesinde Voortrekkers weggesteek word dat sir Harry Smith die twee predikante se onkoste betaal, en dan kon altyd gesê word dat hy dit nie betaal het nie sonder om te verklap dat hy dit na hulle terugkoms wel sou betaal! In die Ring van Kaapstad is egter deur advokaat J. de Wet, die vader van die later so bekende mevrou Koopmans de Wet beswaar gemaak toe vermoed is dat die Goewerneur die onkoste sou betaal, want dan sou die afvaardiging van twee predikante nie meer van suiwer kerklike aard wees nie, waar hul onder die geldelike verpligtings en dus onder die invloed van sir Harry Smith gestaan het. Die Sinodale Kommissie het dit egter vir die Ring geheim gehou dat die Goewerment die onkoste betaal het, en het geweier om enige informasie aan die Ring te gee. ${ }^{26}$

Hierdie twee predikante, en veral ds. William Robertson het die gemoedere van die republikeinsgesindes wat na die anneksasie van die Vrystaat en na die geveg van Boomplaas net warm was, probeer kalmeer maar hy moes versigtig wees. Op 23 November 1848 het hy uit die Vrystaat aan sir Harry Smith geskryf: „We have abstained in our public services from allusion directly to Rebellion, but we embrace every opportunity of speaking very candidly with those who are said to be disaffected, in private, and seldom omit to tell them what has been lately going on in France after they got rid of their King, and we generally take care to obey the Apostolic command by praying for the Queen and all in authority". Ds. Robertson het gemeen dat, soos die Engelsgesinde lojaliste hom meegedeel het, ,nothing would tend more to promote peace and loyalty throughout the country than the settlement of zealous and pious ministers in it." 27 Sir Harry Smith het dan ook rede gehad om baie tevrede te wees met die werk van die twee predikante, en het nadat hulle teruggekom het aan ds. Robertson onder andere geskryf: "With the words of Christ and His Apostles in your hands, so full of wisdom and grace, ministers like yourselves kind and energetic were alone required to show them (naamlik die wat hulle nie aan die Britse gesag wou onderwerp nie) the error of their ways and to prepare them for the life eternal." 28 Hoewel sir Harry Smith wel van mening was dat die vooroordele van baie mense teen die Britse gesag wel nie so gou sou verdwyn nie, het hy tog gehoop ,that want of mutual confidence will be speedily removed by the measures in progress, aided by the Ministers of the Gospel and the churches now in course of erection". ${ }^{1}$ En daarom het hy aan lord Grey, die Sekretaris van Staat vir Kolonies in Londen, geskryf dat sulke besoeke van predikante aan die Voortrekkers aangemoedig moes word. So is die beleid van die geestelike Swaard konsekwent toegepas!

\footnotetext{
"s.Dreyer, bls. 134.

"Dreyer, bls. 140.

${ }^{27}$ Dreyer, bls. 140-141.

"Dreyer, bls. 149.
} 
Soos reeds vermeld het sir Harry Smith op 17 Augustus 1848 in sy „waarschuwing aan de Rebel Boeren" gesê: „Ik heb twee godsdienst Leeraren aan het komen uit Holland." Dit was een van die twee seuns van Ds. Andrew Murray van Graaff-Reinet, John of Andrew, wat in Julie uit Holland vertrek het en na ' $n$ kort verblyf in Skotland by familie in November in Suid-Afrika aangekom het, en die ander was Dirk van Velden. Sir Harry Smith het die twee broers Murray by hul koms in Kaapstad by hom ontbied en aan John gesê: „You are the elder, and therefore I shall give you the charge of Burgersdorp." En aan Andrew het hy gesê: „And as you are the younger, $I$ am afraid I shall have to send you to Bloemfontein." 29 Ds. Andrew Murray is dan ook in Bloemfontein nie deur die Kerkraad beroep nie, maar deur sir Harry Smith aangestel. Die anstelling van Andrew deur sir Harry Smith word reeds in De Geref. Kerkbode van 24 Februarie 1849 vermeld, ${ }^{30}$ maar die kennisgewing van die Goewerneur is eers gedateer 12 Maart 1849.

Sir Harry Smith het op 14 Maart in 'n proklamasie „Regulations for the future Government of the Orange River Souvereignty"31 onder andere ook die Kerk in daardie gebied onder die Kaapse Sinode ingelyf met 'n bepaling wat lui: „The Dutch Churches within the district will be under the supervision of the Synod of the Church in the Colony". En reeds twaalf dae later het hy aan lord Grey die Sekretaris van Kolonies in Engeland oor 'n inlywing van die Transvaalse Gemeentes geskryf: „An arrangement which I shall facilitate as much as lies in my power." 32 Dit is dan ook baie duidelik: sir Harry Smith het daar belang ingestel dat nie alleen die Soewereinteitse maar ook die Transvaalse Gemeentes onder die Kaapse Sinode ingelyf moes word want dan sou hy die finale seggingskap gehad het in die aanstelling van die predikante, nie alleen in die Soewereiniteit nie maar ook in Transvaal. As sy planne sou geslaag het om soos hy aan Potgieter geskryf het om die finale seggingskap in die aanstelling van die Transvaalse militêre leiers en amptenare en ook die finale seggingskap in die aanstelling van die Transvaalse predikante in hande te kry, sou dit die einde van die Transvaalse vryheidsstrewe beteken het.

In April 1851 het sy twee vriende die predikante John en Andrew Murray dan ook in die Kerkraadsvergaderings te Potchefstroom en Rustenburg voorgestel om afgevaardigdes na die Ring van Transgariep te stuur wat uit die gemeentes in Natal en die Soewereiniteit bestaan het en onder die Kaapse Sinode geval het. As hierdie voorstel deurgegaan het sou Transvaalse Gemeentes voortaan ook onder die Kaapse Sinode geval het en sou die planne van sir Harry Smith om oor die finale aanstelling van die Transvaalse predikante te beskik, geslaag het. Die ou

${ }^{2} \mathrm{~J}$. du Plessis: The Life of Andrew Murray (1919) bls. 77. Die anstelling is eers in die Cape of Good Hope Govt. Gazette van 12 Maart 1849 gepubliseer.

${ }^{30}$ Bls. 60 .

"Cape of Good Hope Govt. Gaz. 15 Maart 1849.

${ }^{32}$ Kaapse Argief G.H. 23/18, No. 62. 
Voortrekkers het hierdie planne deursien en het die voorstel met algemene stemme van die ouderlinge en die diakens, in verband met ,politieke zaken" verwerp.

Die beleid van die Geestelike Swaard van sir Harry Smith was in die Soewereiniteit ' $n$ welgeslaagde beleid. Soos reeds gesê het hy in 1850 ds. Andrew Murray as predikant van Bloemfontein aangestel, en in 1848 het hy ds. D. van Velden as predikant van Winburg aangestel, en in 1853 het sy opvolger, goewerneur G. Cathcart, ds. P. Roux as predikant van Smithfield aangestel. Al drie was heftige voorvegters vir die behoud van die Britse Soeweriniteit en die Britse vlag in die Vrystaat.

Op 13 Augustus 1853 was daar 'n vergadering op Bloemfontein van die ingesetenes van die dorp en distrik in verband met die moontlike verlating van die Soewereiniteit deur die Engelse, en verskillende resolusies is aangeneem waarin dit beklemtoon is dat die Britse gesag en die Britse vlag in elk geval gehandhaaf moes bly. Een van die resolusies wat voorgestel is deur Collins en gesekondeer deur ds. Andrew Murray, het as volg gelui: ,That this meeting desires to express its serious apprehensions of the incalculable evil resulting to religion and morality from the abandonment of the sovereignty, there being every reason to fear that the probable weakness of the executive for the suppression of crime the diminution of our religious and educational advantages, with the removal of many of those checks which at present exist to restrain vice, will infallibly tend to the demoralization of the community." Ds. Murray het die aanname van hierdie resolusie kragtiglik bepleit, maar sy toespraak waarmee hy dit gedoen het is ongelukkig nie in die Bloemfonteinse koerant, ,The Friend of the Sovereignty" gerapporteer nie. Waarom dit nie gedoen is nie, weet ons nie. Alleen word gesê: ${ }^{34}$,We exceedingly regret that we are not, owing to unfortunate circumstances, in a position to publish the speech delivered by the Rev. A. Murray, at the public meeting of 13th ult. on the occasion of his supporting the resolution moved by Mr. Collins. All we can do, besides expressing our regret, is to state that a more comprehensive, pointed and telling oratorical panorama, of the state of anarchy and demoraliztion, which would ensure the abandonment of this territory, we have not often had the opportunity and painful pleasure of listening to." Dit lyk baie geheimsinnig. Waarom wou die koerant hierdie toespraak van Ds. Murray nie publiseer nie waarin hy ,the state of Anarchy and demoralization", wat volgens hom sou ontstaan as die Britse gesag sou verdwyn en die gebied 'n Voortrekker-Republiek sou word so meesterlik geskilder het? Verder is daar op dieselfde vergadering besluit om 'n protes teen die opheffing van die Britse Soewereiniteit te publiseer. En verder is daar nege lede gekies om as 'n permanente kommissie op te tree die protes op te stel en verder te protesteer wanneer nodig, om sodoende die Britse gesag te behou. As lede van hierdie kom-

\footnotetext{
${ }^{38}$ Enclosure 3 in No. 2, Report from sir George Clerk to the Duke of New Castle. August 25, 1853.

"The Friend of the Sovereignty, September 1, 1853.
} 
missie is gekies dr. A. J. Fraser, E. U. Stuart, Geo. Home, ds. Andrew Murray, A. Donaldson, T. Jordan, Staunton, J. H. Ford en C. E. Fichardt.

Sir George Russell Clerk het die Voortrekker groep in die Soewereiniteit 'n ontskatbare diens bewys deur in sy rapporte aan die regering in Londen hul standpunt onomwonde te vertolk. Reeds op 25 Augustus 1853 het hy die inlywing van die gebied deur sir Harry Smith veroordeel en dit ,,a crude plan" genoem. ${ }^{35}$ En met nadruk het hy in sy rapport van 10 September 1853 verseker: „The entire Dutch population through the territory, outnumber the English in the proportion of twenty to one. Nevertheless, the untiring zeal of the Scotch Presbyterian clergyman ${ }^{36}$ of the Dutch Church here, and the contrivances suggested by the keen instinct of the few but largely speculating Englishmen, supported by the cordial good will of every man in the Government paid civil establishments, who, though not settlers or intending to be settlers, are active land speculators, seem likely to represent public opinions to be very much the reverse of what I believe it really to be." Op 28 September is dr. A. J. Fraser en ds. Andrew Murray deur die Engelsgesinde groep as afgevaardigdes gekies om na Engeland te gaan en die regering in Londen te probeer beweeg om die Britse gesag in die Vrystaat te handhaaf, en hul standpunt daar te stel. Clerk het dit nodig geag om dadelik die betrokke Minister in Londen teen die beide afgevaardigdes te waarsku en die standpunt van die groot meerderheid van die bevolking, die Boere deel, te stel: „Messrs. Fraser and Murray will by no means represent the feelings and opinions of the majority of the settlers in this territory. The sentiments of that majority continue to be what they ever had been, they are averse to British Administration, on account of wrongs which they remember to have endured under its rule in the Cape colony." Die Vrystaat kan dan ook nie anders as baie erkentelik te wees teenoor sir George Russell Clerk vir sy eerlikheid en kragtige hulp om die saak van die vryheidsgesinde Boere so openhartig in sy rapporte aan die Londense regering te stel, waardeur hul saak so kragtig bevorder is.

Dr. Fraser en ds. Murray het na Engeland vertrek, gewapend met stukke van verskillende Engelsgesinde liggame om hul in hul pogings te steun. Ds. Murray het van minstens drie Ringe van die Kaapse Kerk sulke stukke gekry. So lees ons van Ring van Transgariep wat die gemeentes in Natal en in die Soewereiniteit omvat het op 13 Oktober 1853 op Bloemfontein onder voorsitterskap van ds. A. Murray vergader het, die volgende: ,De voorzitter maakt gewag van een uitnodiging hem gedaan tot eene reis naar Engeland, als afgevaardigde in het belang van de zaken der Souvereiniteit en wordt hierover het gevoelen der Vergadering gevraagd.

„De Vergadering stemt met dit verzoek ten volle in en besluit een doelmatig document van den Ring te doen uitgaan, uit naam der onderscheidene gemeenten, gerigt aan de bevoegde outoriteiten in Engeland en

${ }^{35}$ B.B. No. 1758 van 1854, Public Record Office 667, V.O. 224/1.

${ }^{36} \mathrm{Nl}$. Ds. Andrew Murray. 
van welk document afschrift zal worden overgelegd aan $H$. M.Specialen Commissaris, sir George Russell Clerk." En in die notule van die Ring van Kaapstad wat in dieselfde maand gehou is lees ons die volgende besluit wat met algemene stemme aangeneem is: „Deze Vergadering geve hare diepe en hartelijke belangstelling te kennen, in den toestand waarin een gedeelte onzer Kerk gebracht is, door te kennen geven van het voornemen en verder gebracht zoude worden, door het ten uitvoer brengen, van dit voornemen ons Britsch gezag in de Souvereiniteits landen te doen ophouden, en hare vurige wensch uitdrukke dat die maatregel niet in werking gebracht worde." 37 Die Ring van Swellendam het deur middel van sy voorsitter en scriba die volgende brief regstreeks aan koningin Victoria gerig:

To Her Most Gracious Majesty, Queen Victoria.

May it please Your Majesty!

Swellendam, 28th October, 1853.

The Presbytery of Swellendam, in the Colony of the Cape of Good Hope, consisting of Delegates from the Dutch Reformed Churches of Swellendam, Caledon, George, Riversdale, Breda's Dorp, Mossel Bay, Napier, Knysna and Ladysmith, having, at their annual meeting, on the 12th instant, had under their most serious consideration, the announcement, that Your Majesty has been advised to abandon the territory beyond the Orange River, of which Your Majesty, through Your Majesty's Representative and High Commissioner had assumed the Sovereignty, and fearing for the injurious consequences to the moral and religious interests of Your Majesty's subjects, now settled in the Territory referred to, as well as those of the surrounding Native Tribes, which the announced abandonment seems to the Presbytery to involve; and convinced that such a Resolution could only have been adopted from an insufficient knowledge of all the circumstances,- - which will now be brought fully under Your Majesty's notice,- unanimously resolved to beseech Your Majesty, which we have the honour, in their name, of now doing,for the good of Your Majesty's subjects, and that of the numerous native Tribes, within the aforesaid Territory,-to retain Your Majesty's Sovereignty over the country in question.

We have the honour, in name and by authority of the presbytery, to subscribe ourselves.

Your Majesty's most obedient and Humble Servants,

J. S. S. Ballot v.d.m. Praeses

Wm. Robertson D.D. Scriba.

Op Smithfield waar baie Engelse grondspekulante gewoon het, is op 'n Vergadering van 1 Oktober 1853 die volgende voorstel van ds. $P$. Roux die reeds genoemde predikante van die Ned. Geref. Gemeente,

"7. Dreyer: Korte Levensschets van Ds Andrew Murray (1900) bls. 9 asook die notule van die Ring. 
aangeneem: "That this meeting-with a full knowledge of the circumstances under which the dominion of the British Government was assumed over the Orange River Territory, considers that its abandonment, after five years of occupation, is an atrocious break of faith on the part of the British Government, that it will be productive of incalculable evil to the interests of order and religion-that it will tend to alienate the affections of the loyal and well disposed, and to encourage the elements and discord -that it will be regarded by the native tribes of South Africa as an indication of weakness-encouraging them to renewed Acts of aggression, and that it will expose the British name throughout this land, to derision and contempt."

Die ander predikant wat in die Soewereiniteit was, ds. D. van Velden, het ook met krag hom beywer om die Britse gesag te behou, en hy het met woord en daad die afvaardiging van dr. Fraser en ds. Murray gesteun. Toe die sending van ds. Murray misluk het en die Britse gesag tog opgehef is en die gebied 'n vrye Republiek geword het, die Oranje Vrystaat, was ds. van Velden so teleurgesteld dat hy die Voortrekker Staat verlaat het en na die Kaapkolonie verhuis het. Die eerste Staatspresident J. Hoffman het vir die reëling van sake 'n paar proklamasies uitgevaardig en in een daarvan het hy die verwagting uitgespreek dat die predikante deur hul optrede sal toon ,gezanten van Jezus en geen Politieke agenten te zijn." Ds. van Velden het sy teleurstelling oor die verdwyning van die Britse gesag in 'n brief vol bitterheid gelug, geskrywe met 'n pen wat hy in gal gedoop het. Hierdie brief moes dan op ondergrondse wyse onder die mense sirkuleer ${ }^{38} \mathrm{Hy}$ het hul daarin teen die nuwe Republikeinse Regering gewaarsku en president Hoffman 'n ,vuilen Proclamatiebraker" genoem, sy proklamasie 'n "Liederlijk schrijven" en die Republikeinse owerheid 'n ,,rot" wat ,"met beestachtige domheid en sluwe huichelaary" vervul is, en hul genoem ,goddeloozen en huichelaars die rebellen en oproerlingen in de Kerk van Christus zijn-de kinderen des duivels die God en zijne Gezalfde smaden, en die van dan meer genoemde A. Murray, als van een verrader spreken, en dat volkje is thans gebleven wat het was, en dezelfde kruisgezant Murray zal in hunne verzwaarde verdoemenis gerechtvaardigd worden ten dage als de vraag Hebr. 10:29 zal beantwoord worden." Hy wil ds. Murray dan ook nie teen sulke ,gespuis" verdedig nie. Verder sê hy dat dit sy eie eer en karakter as mens te na kom om hom ",met zulk uitvaagsel van het menschelijk geslaacht te bemoeijen", en nog meer sulke ergerlikhede.

Die vrees van generaal Andries Pretorius vir die Geestelike Swaard was voorwaar geen denkbeeldige vrees nie.

\section{S. P. ENGELBRECHT.}

${ }^{38}$ The Friend of the Sovereignty, 1 Julie 1854, en Dr. G. B. A. Gerderner: Boustowwe, bls. 124-126. 